\title{
DANÇA DE SALÃO: UMA ESTRATÉGIA PARA FAZER EDUCAÇÃO EM SAÚDE COM IDOSOS
}

\author{
Carola Rosas ${ }^{1}$ \\ Nathália A. Nascimento \\ Debora de Souza Santos ${ }^{3}$ \\ Ana Railka de Souza Oliveira-Kumakura ${ }^{3}$ \\ ${ }^{1}$ Doutoranda em Ciências da Saúde - Universidade Estadual de Campinas \\ ${ }^{2}$ Mestranda em Gerontologia - Universidade Estadual de Campinas \\ ${ }^{3}$ Professora Doutora da Faculdade de Enfermagem - Universidade Estadual de Campinas
}

INTRODUÇÃO: Atividade física como dança de salão é uma estratégia adaptativa buscada pelos idosos. A educação em saúde aliada a esta atividade pode servir como ferramenta de promoção da saúde. OBJETIVO: Relatar a experiência de planejamento e desenvolvimento da oficina de dança de salão aliada a ações de educação em saúde para a promoção da saúde do idoso. METODOLOGIA: Trata-se de um relato de experiência do planejamento e implementação de um projeto de extensão intitulado "Quero ser seu par: dança de salão com saúde", O projeto faz parte da grade curricular da disciplina "Qualidade de vida e funcionalidade na velhice", do curso de pós-graduação da Faculdade de Enfermagem (Fenf), da Universidade Estadual de Campinas (Unicamp) e é inserido como oficina do "Programa UniversIDADE" da mesma instituição. As atividades foram realizadas na Unicamp, no prédio da Fenf, com início no dia 26 de abril de 2018 e sendo realizado um encontro semanal de duas horas de duração que continha um momento de educação em saúde e outro com aulas práticas de dança ministradas por professor especializado. No total foram realizadas cinco encontros. RESULTADOS: 33 pessoas participaram das oficinas entre a faixa etária de 51 a 80 anos, na sua maioria foram mulheres $(90,9 \%)$. No primeiro encontro foi realizado o diagnóstico dos integrantes através do questionário de Índice de Vulnerabilidade clínico funcional e a partir das demandas que surgiram, foi realizado o planejamento das oficinas educativas seguintes, correspondentes ao $2^{\circ}, 3^{\circ} \mathrm{e} 4^{\circ}$ dia, tendo como temas: "Benefícios da dança de salão", "Alimentação saudável" e "Memória" e no último encontro foi realizada a avaliação da oficina. Em seguida ao momento educativo, os integrantes seguiam para o momento prático da aula de dança de salão. CONSIDERAÇÕES FINAIS: A ligação da dança e educação como um só torna-se uma importante estratégia na promoção do envelhecimento ativo. Ao incorporar neste processo ao indivíduo de forma integral o processo de ensino valoriza a 
participação ativa do idoso a partir do seu contexto social e cultural, e a atividade educativa influencia o caminho para um envelhecimento bem sucedido. Torna-se essencial que os profissionais da saúde envolvam práticas inovadoras de conteúdo educativo com os adultos de 50 anos e mais.

Palavras-chave: Educação em saúde. Idoso. Dança. 